\title{
Quality assessment of heat-treated wood by NIR spectroscopy
}

\author{
Bruno Esteves $\cdot$ Helena Pereira
}

Published online: 31 July 2008

(C) Springer-Verlag 2008

\begin{abstract}
NIR spectroscopy was tested for predicting the properties of heat treated wood using pine (Pinus pinaster) and eucalypt (Eucalyptus globulus) woods with two types of treatment: in oven and in a steam autoclave. Mass loss, equilibrium moisture content, dimensional stability, MOE, bending strength, colour CIELAB parameters and extractives content were determined. NIR spectra were obtained using a fibre probe on the radial surface of the samples. NIR models for mass loss showed very high coefficients of determination $\left(R^{2}\right)$ for cross validation ranging from 96$98 \%$. The models obtained for wood properties were in general good with coefficients of determination ranging from $78-95 \%$ for equilibrium moisture content, $53-78 \%$ for dimensional stability, $47-89 \%$ for MOE, 75-77\% for bending strength and 84-99\%, 52-96\% and 66-98\% for colour parameters $L, a^{*}$ and $b^{*}$, respectively. $R^{2}$ of the models for extractive content varied between $41.9-79.8 \%$ for pine and between $35.3-82.2 \%$ for eucalypt wood. NIR spectroscopy showed a good potential for quality control and characterization of heat treated woods.
\end{abstract}

B. Esteves (『)

Centro de Estudos em Educação, Tecnologias e Saúde, ESTV, Instituto Politécnico de Viseu,

Av. Coronel José Maria V. de Andrade, Campus Politécnico, 3504-510 Viseu, Portugal

e-mail: bruno@demad.estv.ipv.pt

\section{H. Pereira}

Centro de Estudos Florestais, Instituto Superior de Agronomia,

Universidade Técnica de Lisboa,

Tapada da Ajuda,

1349-017 Lisboa, Portugal

\section{Qualitätsbewertung von wärmebehandeltem Holz mittels NIR-Spektroskopie}

Zusammenfassung Untersucht wurde die Möglichkeit, die Eigenschaften von wärmebehandeltem Kiefern- (Pinus pinaster) und Eukalyptusholz (Eucalyptus globulus) mit Hilfe von NIR-Spektroskopie zu bestimmen. Dabei wurde das Holz auf zwei verschiedene Arten wärmebehandelt, im Ofen und im Autoklaven. Masseverlust, Gleichgewichtsfeuchte, Dimensionsstabilität, Elastizitätsmodul, Biegefestigkeit, CIELAB Farbparameter und Extraktstoffgehalt wurden bestimmt. Die NIR-Spektren wurden mit einer Fasersonde auf der radialen Oberfläche der Prüfkörper ermittelt. NIR-Modelle zur Bestimmung des Masseverlusts ergaben ein sehr hohes Bestimmtheitsmaß $\left(R^{2}\right)$ von 96$98 \%$. Die für die Holzeigenschaften ermittelten Modelle waren generell gut. Das Bestimmtheitsmaß für die Gleichgewichtsfeuchte lag zwischen 78-95\%, für die Dimensionsstabilität zwischen $53-78 \%$, für den Elastizitätsmodul zwischen 47-89\%, für die Biegefestigkeit zwischen 75$77 \%$ und für die Farbparameter $L, a^{*}$ und $b^{*}$ zwischen 84-99\%, 52-96\% sowie 66-98\%. Das Bestimmtheitsmaß für den Extraktstoffgehalt von Kiefernholz schwankte zwischen 41,9-79,8\% und das von Eukalyptusholz zwischen 35,3-82,2\%. Die NIR-Spektroskopie erwies sich somit als ein gut geeignetes Verfahren zur Qualitätskontrolle und Beurteilung von wärmebehandeltem Holz.

\section{Introduction}

The use of near infrared spectroscopy (NIR) as a method to determine chemical composition and properties of lignocellulosic materials has increased very much since its first application to agricultural materials nearly 50 years 
ago (Osborne et al. 1993). The research on wood characterization by NIR is booming and many publications show successful results, namely related to the determination of chemical composition (Schultz and Burns 1990, Schimleck et al. 1997, Poke et al. 2004, Alves et al. 2006, Rodrigues et al. 2006). NIR was also used to detect or determine extractives like pinosylvins in Scots pine (Holmgren et al. 1999), phenolics in larch (Gierlinger et al. 2002) or total extractives in Eucalyptus globulus (Poke et al. 2004).

NIR has been used to predict some physical properties of wood like moisture content (Tsuchikawa et al. 1996), density (Schimleck and Evans 2003) or stiffness (Jones et al. 2005).

The use of NIR spectroscopy for the estimation of mechanical properties by a non destructive analysis using an optical-fibre probe is new. Hoffmeyer and Pedersen (1995) studied the correlations between NIR spectra and, compression and bending strength. Thumm and Meder (2001) reported that NIR could be used to predict the modulus of elasticity (MOE) and Gindl et al. (2001) obtained good calibrations for MOE of Larix decidua wood. Schimleck et al. (2005) used NIR to estimate specific gravity, MOE and modulus of rupture (MOR) of loblolly pine.

The characterization of heat treated wood using NIR spectroscopy was suggested by Hinterstoisser et al. (2003) who considered that NIR spectra of milled wood removed from the surface of heat treated wood could be used for classification purposes. A close relationship between chemical changes and NIR spectra of thermally modified beech wood was reported (Schwanninger et al. 2004).

Heat treatment is an environmentally benign process to reduce equilibrium moisture content of wood and improve its dimensional stability and durability along with a small increase in wood resistance to weathering that evolved recently to commercial processes in some European and American countries (Dirol and Guyonnet 1993, Viitaniemi et al. 1997, Jämsa et al. 2000, Kamdem et al. 2002). Heat treated wood has a large application for outdoor use in cladding, decks, garden furniture and window frames and indoors for kitchen furniture, parquet, decorative panels and mainly for the interior of saunas. Mass loss during treatment is often used as a measure of heat treated wood quality but for most of the species mass loss depends on the extractive content and composition since volatile compounds are the first to leave the wood when wood is submitted to heat. Other quality control methods were reported, i.e. high energy multiple impact (Rapp et al. 2006) and CIELAB colour measurements (Brischke et al. 2007) but the first is a destructive analysis and the second only gave significant correlations with milled wood.

NIR spectroscopy has therefore the potential to be used in quality control of heat treated wood, with the advantage of allowing predictions of several other properties.
In this work, NIR was used to estimate mass loss and the following properties of heat treated wood: equilibrium moisture content, dimensional stability, MOE, bending strength, colour parameters and extractive content. NIR spectra were collected using an optical-fibre probe on the wood surface to study the possibility of integrating this method in the production line of heat treated wood to evaluate quality through a non destructive and fast process.

\section{Material and methods}

The wood of two important species in Portugal, eucalypt (Eucalyptus globulus Labill.) and pine wood (Pinus pinaster Aiton) were used in this work. The heat treatment with hot air was made in an oven with heated air at temperatures in the range of $170-200^{\circ} \mathrm{C}$ and with different durations from 2 to $24 \mathrm{~h}$, and the treatment with steam was performed in an autoclave with a mixture of superheated and saturated steam at $190-210^{\circ} \mathrm{C}$ for $2-12 \mathrm{~h}$, as reported in Esteves et al. (2007a,b). The cubic samples, $40 \mathrm{~mm}$ edge, were weighed and measured in transversal, tangential and radial directions and mass loss with heat treatment was determined in relation to initial dry mass as Mass loss (\%) $=\frac{W_{\mathrm{t}}-W_{\mathrm{nt}}}{W_{\mathrm{nt}}}$, where $W_{\mathrm{t}}$ is the dry mass of treated wood and Wnt the dry mass of untreated wood. Equilibrium moisture content and dimensional stability in transversal, tangential and radial directions were determined at 35, 65 and $85 \%$ relative humidity. Dimensional stability was measured as ASE (anti shrinking efficiency) calculated as: $\operatorname{ASE}(\%)$ $=\left(\frac{S_{\mathrm{nt}}-S_{\mathrm{t}}}{S_{\mathrm{nt}}}\right) 100$ where $S_{\mathrm{nt}}$ and $S_{\mathrm{t}}$ represent the shrinking between the desired relative humidity and $0 \%$ relative humidity for non treated (nt) and treated ( $\mathrm{t}$ ) samples. MOE and bending strength were determined by a 3 -point static bending test with $360 \times 20 \times 20 \mathrm{~mm}^{3}$ (axial $\times$ radial $\times$ tangential) samples. Measurements were made using a constant velocity of $0.3 \mathrm{~mm} / \mathrm{min}$ for $\mathrm{MOE}$ and a velocity estimated to cause rupture in three minutes for bending strength. MOE and bending strength were determined according to: $\operatorname{MOE}\left(\mathrm{N} / \mathrm{mm}^{2}\right)=\frac{\Delta F * L^{3}}{\Delta x * 4 * b * h^{3}}$, Bending strength $(\mathrm{MPa})=\frac{3 * F * L}{2 * b * h^{\frac{10}{6}}}$, where $F$ is the load on rupture in $N$, $\frac{\Delta F}{\Delta x}$ is the slope of the elastic zone in $\mathrm{N} / \mathrm{mm}, L$ is the arm length, $h$ the height and $b$ the width all expressed in $\mathrm{mm}$. The colour measurements were made in a Minolta CM3630 spectrophotometer by the CIELAB method as reported by Esteves et al. (2007c).

Extractive content was determined by successive Soxhlet extraction of about $3 \mathrm{~g}$ of each sample using successively $150 \mathrm{ml}$ of dichloromethane, ethanol and water during 10 hours for dichloromethane and 20 hours for ethanol and water. 
The samples were kept in a conditioned room at $20^{\circ} \mathrm{C}$ and $50 \%$ relative humidity for two weeks prior to analysis. The NIR measurements were made on the wood surface before and after each heat treatment in a Bruker Vector 22/N spectrophotometer, using 50 scans for each spectrum. On the $40 \mathrm{~mm}$-edge samples, eight measurements were made on the radial surface along the tangential direction in order to cover the entire surface and on the 20 mm-edge samples used for mechanical assays five measurements were made. Each value represents the average of all the spectra for the same sample. The results concern all the temperatures and times of treatment except for mechanical properties where only some of the samples were analyzed.

The method used for the construction of calibration models was the partial least-squares regression (PLS), determining the percentage of explained variation $\left(R^{2}\right)$, the random square error for cross validation (RMSECV) and the number of main components necessary to explain the variation of the models (rank) using OPUS 4.2 Quant 2 software (Bruker).

The models were constructed for: mass loss with heat treatment, equilibrium moisture content, dimensional stability (measured as ASE), apparent modulus of elasticity (MOE), bending strength, colour parameters $\left(L^{*}, a^{*}\right.$ and $\left.b^{*}\right)$ and dichloromethane, ethanol, water and total extractives. Several pre-processing methods for the NIR data were used as available from the software and the best models for each variable were chosen.

\section{Results and discussion}

\subsection{Mass loss}

Although mass loss is not a wood property per se, it is an important variable in the production of heat treated wood since it is in relation with the resulting variation in wood properties (Viitaniemi et al. 1997, Jämsä and Viitaniemi 2001, Kamdem et al. 2002, Wang and Cooper 2005, Hakkou et al. 2006, Esteves et al. 2007a,b). Therefore, calibration curves were developed as an indirect method to predict wood mass loss by heat treatment using pine ( $\mathrm{Pi}$ nus pinaster) and eucalypt wood (Eucalyptus globulus) as the model species and two treatment methods, respectively hot air in an oven and steam in an autoclave. Mass loss with heat treatment ranged from $0.0-12.0 \%$ and $0.1-10.6 \%$ for pine and eucalypt wood treated with hot air and from $0.3-8.7 \%$ and $3.9-14.9 \%$ for pine and eucalypt steam heat treated wood, respectively. The higher mass losses result from more intensive treatments (higher temperatures and treatment duration) as discussed in detail by Esteves et al. (2007a,b).
Table 1 Sample characteristics and selected models for mass loss with heat treatment for pine and eucalypt wood

Tabelle 1 Anzahl und Art der Proben und ausgewählte Modelle zur Beschreibung des

Masseverlusts von

wärmebehandeltem Kiefern- und Eukalyptusholz

Fig. 1 Experimental and predicted values for pine and eucalypt wood mass loss (\%) with heat treatment Abb. 1 Experimentell bestimmter und berechneter Masseverlust (\%) von wärmebehandeltem Kiefern- und Eukalyptusholz

\begin{tabular}{|c|c|c|c|c|c|c|c|}
\hline & & $\begin{array}{c}\text { No of } \\
\text { samples }\end{array}$ & $\begin{array}{l}\text { Mass loss } \\
\text { amplitude } \\
(\%)\end{array}$ & $R^{2}$ & RMSECV & Pre-processing & $\begin{array}{c}\text { Spectral region } \\
\left(\mathrm{cm}^{-1}\right)\end{array}$ \\
\hline \multirow[t]{2}{*}{$\overline{\text { Pine }}$} & Oven & 89 & $0.01-11.73$ & 98.0 & 0.421 & Min-max normalization & $7498.3-5446.3$ \\
\hline & Autoclave & 45 & $0.34-8.65$ & 96.4 & 0.411 & $\begin{array}{c}\text { Multiplicative } \\
\text { scattering correction }\end{array}$ & $\begin{array}{l}6102-5774.1 \\
9750.8-6102\end{array}$ \\
\hline \multirow[t]{2}{*}{ Eucalypt } & Oven & 90 & $0.10-10.60$ & 97.2 & 0.491 & $\begin{array}{l}\text { 1st Derivative } \\
\text { and vectorial } \\
\text { normalization }\end{array}$ & $9986.1-5099.1$ \\
\hline & Autoclave & 45 & $3.91-14.87$ & 96.4 & 0.586 & 1st Derivative & $7502.1-5446.3$ \\
\hline
\end{tabular}
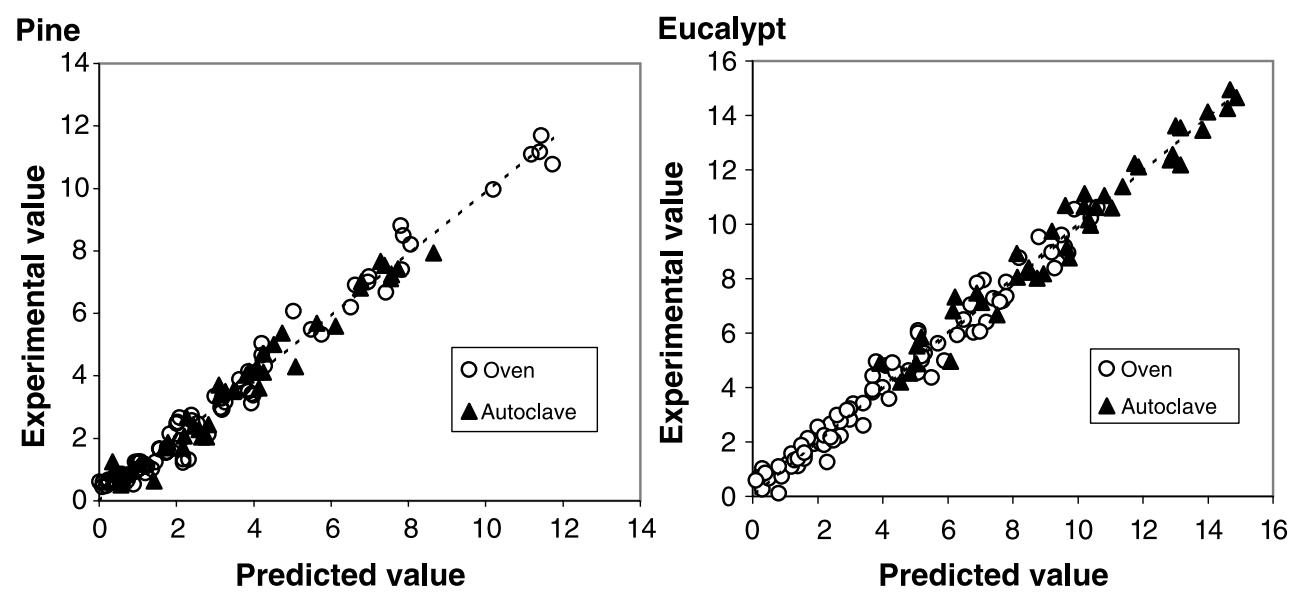
Table 1 presents some characteristics of the samples and of the best models obtained for mass loss. The determination coefficients for cross validation were quite good ranging from $96.4 \%$ (autoclave treatment) to $98.0 \%$ (pine, oven treatment). This was to be expected since mass loss is essentially due to wood degradation mainly of hemicelluloses, and to loss of initial extractives. In fact, good NIR calibrations were reported for hemicelluloses content (Schimleck et al. 1997) and for extractives (Poke et al. 2004). The average random square error for cross validation (RMSECV) ranged from 0.411 (autoclave treatment, pine) to 0.586 (autoclave treatment, eucalypt). The best models for mass loss were obtained using different pre-processing techniques.

Predicted mass losses plotted in function of experimentally determined values are shown in Fig. 1 showing the good prediction ability of all the models. It is interesting to notice that there is no influence of treatment type (oven or steam autoclave) in the prediction ability of the models.

\subsection{Mechanical properties}

The estimation of mechanical properties of wood by NIR is of high practical importance since the experimental wood testing requires destructive and expensive methods. Several models for the prediction of mechanical properties by NIR spectra were developed for the treated wood.

Table 2 presents some characteristics of samples and of the best models for MOE and bending strength. Good calibrations were obtained for $\operatorname{MOE}\left(R^{2}=89.3 \%\right)$ and bending strength $\left(R^{2}=76.9 \%\right)$ of heat treated pine wood but for eucalypt the calibration results were lower with $R^{2}=47.1 \%$ for MOE and $R^{2}=74.5 \%$ for bending strength. The average random square errors for cross validation were $15 \mathrm{MPa}$ for bending strength of both species and $1020 \mathrm{MPa}$ and $1530 \mathrm{MPa}$ for MOE of pine and eucalypt wood, respectively.

Predicted vs. experimental values are plotted in Figs. 2 and 3. The model for pine bending strength was satisfactory because the prediction capacity was quite good although the $R^{2}$ was not very high. Predictions were either under or over-estimated for all of the models with no clear predominance except the predictions for eucalypt MOE which are underestimated up tol about $16000 \mathrm{MPa}$ and overestimated afterwards (Figs. 2 and 3).

These results are not much different from the ones reported by several authors for untreated wood. For instance, Gindl et al. (2001) obtained a better coefficient of determination with clear Larix decidua wood $\left(R^{2}=92 \%\right)$ but Kelley et al. (2004b) obtained only a $R^{2}$ of $77 \%$ for MOE of Pinus taeda. Schimleck et al. (2001) obtained a $R^{2}$ of $77 \%$ for Eucalyptus delegatensis wood while Schimleck et al. (2005) reported a good calibration curve with $R^{2}$ of $86 \%$ for modulus of rupture (MOR) and a slightly poorer calibration $\left(R^{2}=77 \%\right)$ for MOE of loblolly pine. Kelley et al. (2004a) used NIR measurements to predict MOE and MOR of six different softwoods with clear wood and reported $R^{2}$ ranging from 48 to $83 \%$ for MOE and from 64 to $85 \%$ for MOR The worse results obtained for eucalypt wood may be partially explained by the smaller amplitude of wood properties in the eucalypt samples compared to pine wood. The major reason is probably because cross grain in eucalypt wood decreases the orientation differences of the samples and caused some to bend slightly during heat treatment thereby influencing the results.

Since the estimation of wood properties was based on surface scans, a potential source of prediction error may result from an eventual difference between the surface and the wood core in the heat treated samples due to slightly different chemical transformations induced by the temperatureduration gradients within the sample.

\subsection{Equilibrium moisture and dimensional stability}

Equilibrium moisture content is an important property in the evaluation of heat treated wood quality in relation to the increase in dimensional stability and durability, which are two main targets for this type of wood improvement. The characteristics of the samples and the best NIR calibration models to predict equilibrium moisture and tangential $\mathrm{ASE}_{85 \%}$ are reported in Table 3.

Oven heat treated wood presented the best models for moisture with $R^{2}$ of $94.6 \%$ and RMSECV of 0.384 for pine wood and $R^{2}=91.5 \%$ and RMSECV of 0.453
Table 2 Sample characteristics and selected models for MOE and bending strength for pine and eucalypt wood

Tabelle 2 Anzahl und Art der Proben und ausgewählte Modelle zur Beschreibung des E-Moduls und der Biegefestigkeit von Kiefern- und Eukalyptusholz

\begin{tabular}{|c|c|c|c|c|c|c|c|}
\hline & Property & $\begin{array}{l}\text { No of } \\
\text { samples }\end{array}$ & Amplitude & $R^{2}$ & RMSECV & Pre-processing & $\begin{array}{c}\text { Spectral region } \\
\left(\mathrm{cm}^{-1}\right)\end{array}$ \\
\hline \multirow[t]{2}{*}{ Pine } & $\begin{array}{l}\mathrm{MOE} \\
(\mathrm{MPa})\end{array}$ & 57 & $8235-20020$ & 89.3 & 1020 & $\begin{array}{c}\text { Vectorial } \\
\text { normalization }\end{array}$ & $10001.5-6098.1$ \\
\hline & $\begin{array}{c}\text { Bending } \\
\text { strength } \\
\text { (MPa) }\end{array}$ & 57 & $55-172$ & 76.9 & 15 & $\begin{array}{c}\text { Min-max } \\
\text { normalization }\end{array}$ & $8751.8-7498.3$ \\
\hline \multirow[t]{2}{*}{ Eucalypt } & $\begin{array}{l}\text { MOE } \\
(\mathrm{MPa})\end{array}$ & 54 & 12510-20640 & 47.1 & 1530 & $\begin{array}{c}\text { Multiplicative } \\
\text { scattering correction }\end{array}$ & $7502.1-5099.1$ \\
\hline & $\begin{array}{c}\text { Bending } \\
\text { strength } \\
(\mathrm{MPa})\end{array}$ & 54 & 53-172 & 74.5 & 15 & $\begin{array}{l}\text { 1st Derivative and } \\
\text { linear subtraction }\end{array}$ & $10001.5-7498.3$ \\
\hline
\end{tabular}


Fig. 2 Experimental and predicted values for MOE (MPa) of pine and eucalypt heat treated wood

Abb. 2 Experimentell E-Modul (MPa) von wärmebehandeltem Kiefern- und Eukalyptusholz bestimmter und berechneter
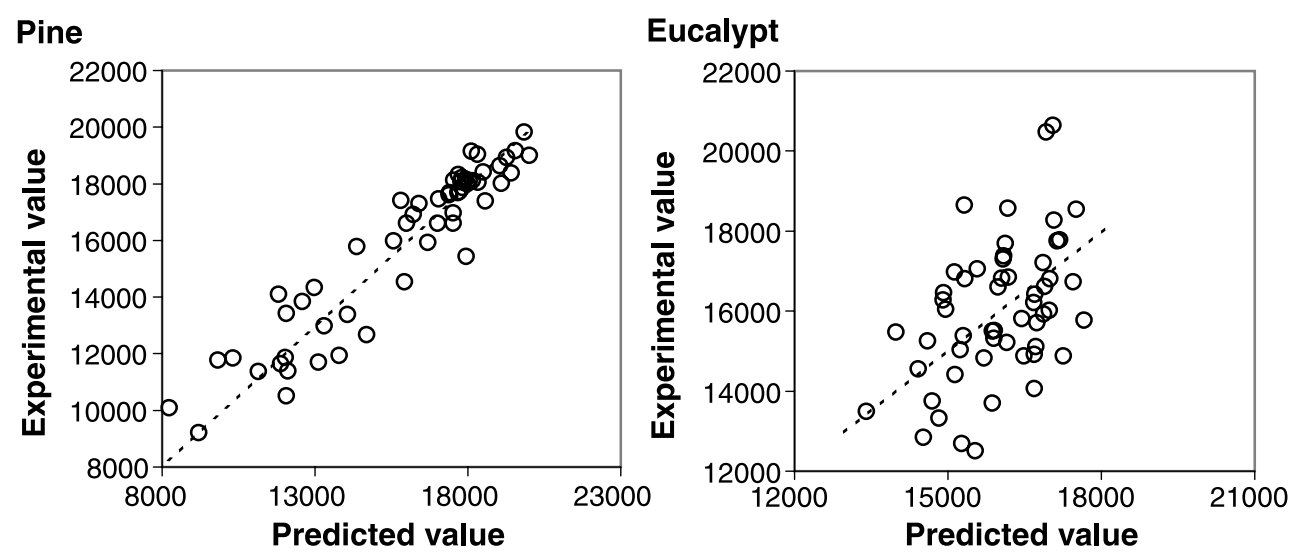

Fig. 3 Experimental and predicted values for pine and eucalypt heat treated wood bending strength (MPa) Abb. 3 Experimentell bestimmte und berechnete Biegefestigeit (MPa) von wärmebehandeltem Kiefern- und Eukalyptusholz

\section{Pine}

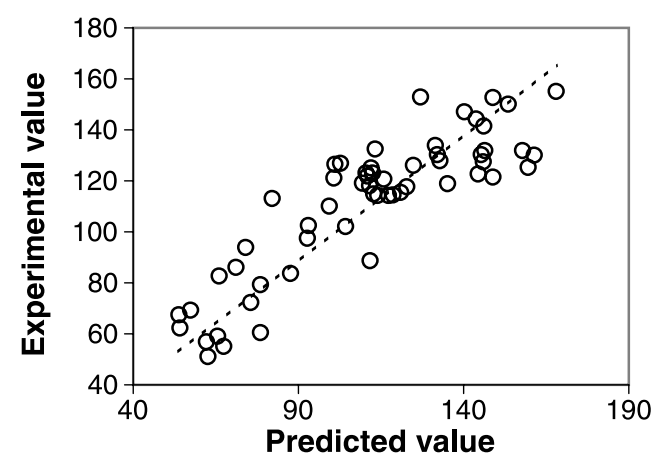

\section{Eucalypt}

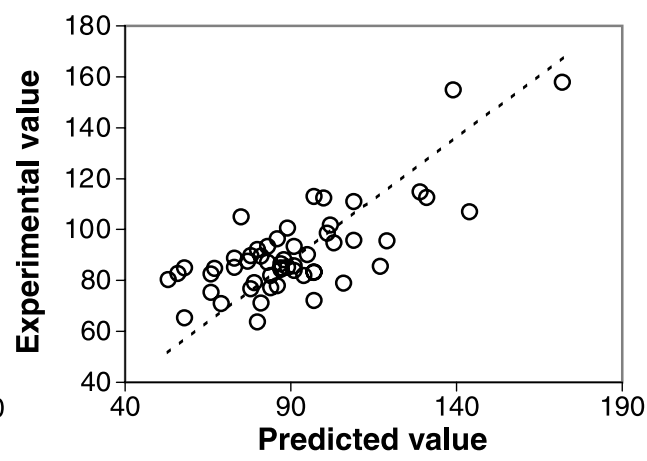

Table 3 Sample characteristics and selected models for equilibrium moisture and dimensional stability ( $\mathrm{ASE}_{85 \%}$ ) for heat treated pine and eucalypt wood

Tabelle 3 Anzahl und Art der Proben und ausgewählte Modelle zur Beschreibung der

Gleichgewichtsfeuchte und der Dimensionsstabilität ( $\left.\mathrm{ASE}_{85 \%}\right)$ von wärmebehandeltem Kiefernund Eukalyptusholz

\begin{tabular}{|c|c|c|c|c|c|c|c|}
\hline & Property & $\begin{array}{c}\text { No of } \\
\text { samples }\end{array}$ & Amplitude & $R^{2}$ & RMSECV & $\begin{array}{c}\text { Pre- } \\
\text { processing }\end{array}$ & $\begin{array}{c}\text { Spectral region } \\
\left(\mathrm{cm}^{-1}\right)\end{array}$ \\
\hline \multirow[t]{2}{*}{$\begin{array}{l}\text { Autoclave } \\
\text { treated } \\
\text { eucalypt }\end{array}$} & $\begin{array}{l}\text { Equilibrium } \\
\text { moisture } \\
(\%)\end{array}$ & & $7.7-9.7$ & 77.8 & 0.26 & $\begin{array}{c}\text { Vectorial } \\
\text { normalization }\end{array}$ & $\begin{array}{r}9750.8-7498.3 \\
6102-5446.3\end{array}$ \\
\hline & $\begin{array}{c}\text { Tangential } \\
\operatorname{ASE}_{85}(\%)\end{array}$ & 45 & $9.3-63.4$ & 53.4 & 4.23 & $\begin{array}{c}\text { No pre- } \\
\text { processing }\end{array}$ & $\begin{array}{r}10001.5-8748 \\
6102-5446.3\end{array}$ \\
\hline \multirow[t]{2}{*}{$\begin{array}{l}\text { Oven } \\
\text { treated } \\
\text { eucalypt }\end{array}$} & $\begin{array}{l}\text { Equilibrium } \\
\text { moisture } \\
(\%)\end{array}$ & 90 & $7.6-13.3$ & 91.5 & 0.453 & $\begin{array}{l}\text { 1st Derivative } \\
\text { and linear } \\
\text { subtraction }\end{array}$ & $\begin{array}{l}7502.1-6098.1 \\
5450.1-5099.1\end{array}$ \\
\hline & $\begin{array}{c}\text { Tangential } \\
\operatorname{ASE}_{85}(\%)\end{array}$ & 90 & $40.9-70.9$ & 64.7 & 7.09 & $\begin{array}{l}\text { 1st Derivative } \\
\text { and vectorial } \\
\text { normalization }\end{array}$ & $\begin{array}{c}11999.5-9747 \\
5276.6-5099.1\end{array}$ \\
\hline \multirow[t]{2}{*}{$\begin{array}{l}\text { Autoclave } \\
\text { treated } \\
\text { Pine }\end{array}$} & $\begin{array}{l}\text { Equilibrium } \\
\text { moisture } \\
(\%)\end{array}$ & 45 & $11.9-15.5$ & 86.1 & 0.36 & $\begin{array}{l}\text { Multiplicative } \\
\text { scattering } \\
\text { correction }\end{array}$ & $7502.1-6098.1$ \\
\hline & $\begin{array}{c}\text { Tangential } \\
\operatorname{ASE}_{85}(\%)\end{array}$ & 45 & $-0.6-49.1$ & 78.1 & 2.99 & $\begin{array}{l}\text { Multiplicative } \\
\text { scattering } \\
\text { correction }\end{array}$ & $\begin{array}{r}8751.8-7498.3 \\
6102-5446.3\end{array}$ \\
\hline \multirow[t]{2}{*}{$\begin{array}{l}\text { Oven } \\
\text { treated } \\
\text { pine }\end{array}$} & $\begin{array}{l}\text { Equilibrium } \\
\text { moisture } \\
(\%)\end{array}$ & 89 & $9.0-15.2$ & 94.6 & 0.38 & $\begin{array}{c}\text { Vectorial } \\
\text { normalization }\end{array}$ & $11999.5-6098.1$ \\
\hline & $\begin{array}{c}\text { Tangential } \\
\operatorname{ASE}_{85}(\%)\end{array}$ & 89 & $20.7-45.7$ & 73.2 & 5.48 & 1st Derivative & $11999.5-7498.3$ \\
\hline
\end{tabular}

for eucalypt wood. Despite the good prediction ability, both models had a high rank, 10 and 5, respectively. The models for autoclave heat treated wood were poorer with a $R^{2}$ of 86.1 and $77.8 \%$ and RMSECV of
0.360 and 0.260 for pine and eucalypt wood, respectively. This difference might be partially explained by the higher amplitude of the data for the oven treatment models. 
Fig. 4 Experimental and predicted value for heat treated pine and eucalypt wood equilibrium moisture $(\%)$ Abb. 4 Experimentell bestimmte und berechnete

Gleichgewichtsfeuchte (\%) von wärmebehandeltem Kiefern- und Eukalyptusholz



\section{Eucalypt}

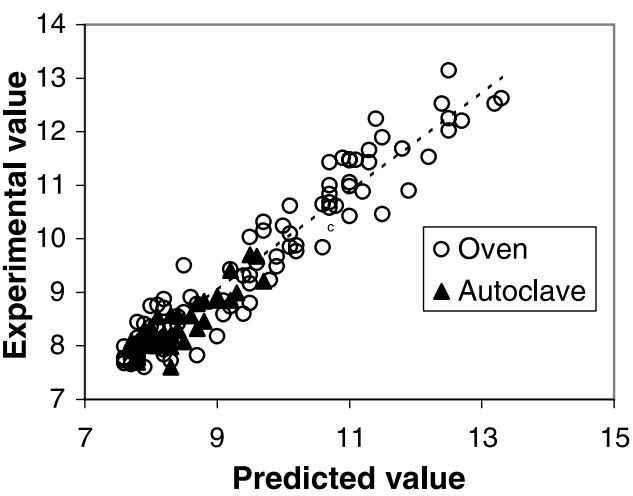

Pine

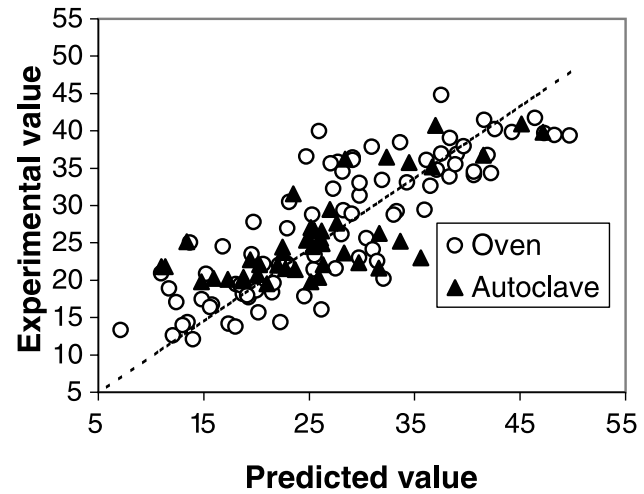

Eucalypt

predicted value for heat treated pine and eucalypt wood dimensional stability (\%) Abb. 5 Experimentell bestimmte und berechnete

Dimensionsstabilität (\%) von wärmebehandeltem Kiefern- und Eukalyptusholz
Table 4 Sample characteristics and selected models for colour parameters of oven and autoclave heat treated pine and eucalypt wood

Tabelle 4 Anzahl und Art der Proben und ausgewählte Modelle zur Beschreibung der

Farbparameter von wärmebehandeltem Kiefern- und Eukalyptusholz

\begin{tabular}{|c|c|c|c|c|c|c|c|}
\hline & Property & $\begin{array}{c}\text { No of } \\
\text { samples }\end{array}$ & Amplitude & $R^{2}$ & RMSECV & Pre-processing & $\begin{array}{l}\text { Spectral region } \\
\left(\mathrm{cm}^{-1}\right)\end{array}$ \\
\hline \multirow{3}{*}{$\begin{array}{l}\text { Autoclave } \\
\text { treated } \\
\text { Pine }\end{array}$} & $L^{*}(\%)$ & 45 & $35.9-55.0$ & 83.5 & 1.94 & Linear subtraction & $\begin{array}{r}10001.5-7498.3 \\
5276.6-5099.1\end{array}$ \\
\hline & $a^{*}$ & 45 & $7.3-9.5$ & 51.6 & 0.35 & $\begin{array}{l}\text { Elimination of } \\
\text { constant offset }\end{array}$ & $\begin{array}{r}9920.5-5099.1 \\
10001.5-6098.1\end{array}$ \\
\hline & $b^{*}$ & 45 & $15.9-22.4$ & 66.1 & 1.17 & $\begin{array}{c}\text { Min-max } \\
\text { normalization }\end{array}$ & $9920.5-5099.1$ \\
\hline \multirow{3}{*}{$\begin{array}{l}\text { Oven } \\
\text { treated } \\
\text { pine }\end{array}$} & $L^{*}(\%)$ & 89 & $30.9-75.2$ & 98.7 & 1.4 & No pre-processing & $\begin{array}{r}11999.5-7498.3 \\
5450.1-5099.1\end{array}$ \\
\hline & $a^{*}$ & 89 & $6.6-13.6$ & 88.7 & 0.54 & $\begin{array}{c}\text { Vectorial } \\
\text { normalization }\end{array}$ & $\begin{array}{r}11999.5-7498.3 \\
6102-5774.1\end{array}$ \\
\hline & $b^{*}$ & 89 & $11.1-31.1$ & 96.4 & 1.1 & $\begin{array}{c}\text { Vectorial } \\
\text { normalization }\end{array}$ & $\begin{array}{r}11999.5-7498.3 \\
6102-5446.3\end{array}$ \\
\hline \multirow[t]{3}{*}{$\begin{array}{l}\text { Autoclave } \\
\text { treated } \\
\text { eucalypt }\end{array}$} & $L^{*}(\%)$ & 45 & $27.9-43.8$ & 94.8 & 0.9 & $\begin{array}{l}\text { 1st Derivative } \\
\text { and vectorial } \\
\text { normalization }\end{array}$ & $\begin{array}{r}10001.5-7498.3 \\
6102-5446.3\end{array}$ \\
\hline & $a^{*}$ & 45 & $4.3-10.1$ & 96.4 & 0.285 & $\begin{array}{l}\text { 1st Derivative } \\
\text { and vectorial } \\
\text { normalization }\end{array}$ & $\begin{array}{r}8751.8-7498.3 \\
6102-5446.3\end{array}$ \\
\hline & $b^{*}$ & 45 & $5.8-16.4$ & 97.6 & 0.425 & $\begin{array}{l}\text { 1st Derivative and } \\
\text { linear subtraction }\end{array}$ & $\begin{array}{r}10001.5-7498.3 \\
6102-5446.3\end{array}$ \\
\hline \multirow[t]{3}{*}{$\begin{array}{l}\text { Oven } \\
\text { treated } \\
\text { eucalypt }\end{array}$} & $L^{*}(\%)$ & 90 & $25.4-59.3$ & 98.7 & 1.02 & $\begin{array}{l}\text { 1st Derivative } \\
\text { and vectorial } \\
\text { normalization }\end{array}$ & $\begin{array}{r}11999.5-9747 \\
6102-5446.3\end{array}$ \\
\hline & $a^{*}$ & 90 & $5.0-11.2$ & 94.8 & 0.353 & $\begin{array}{l}\text { 1st Derivative } \\
\text { and vectorial } \\
\text { normalization }\end{array}$ & $\begin{array}{r}9750.8-7498.3 \\
6102-5446.3\end{array}$ \\
\hline & $b^{*}$ & 90 & $5.8-21.7$ & 97.3 & 0.742 & $\begin{array}{l}\text { 1st Derivative and } \\
\text { linear subtraction }\end{array}$ & $7502.1-5099.1$ \\
\hline
\end{tabular}


The results reported by some authors for untreated wood are similar to those obtained for the oven treatment. For instance, Hoffmeyer and Pedersen (1995) reported determination coefficients higher than $90 \%$ for Norway spruce, and Thygesen and Lundqvist (2000a,b) referred that NIR measurements of moisture content in wood depend on the temperature. All of the models for moisture behaved well with no clear predominance between under or over estimated samples (Fig. 4).

In relation to the dimensional stability, the prediction capacity of all models proved to be relatively weak with coefficients of determination for cross validation of 73.2 and $78.1 \%$ for pine and 64.7 and $53.4 \%$ for eucalypt wood treated in oven and autoclave, respectively. Baillères et al. (2002) reported a $R^{2}$ of $82 \%$ for tangential shrinkage and $65 \%$ for radial shrinkage for a hybrid of E. urophylla $\mathrm{X}$ E.grandis and for grounded wood which shows the difficulty of obtaining good correlations for dimensional stability.

Despite the relatively low predicted ability of the models NIR can be used to give an approximated value for dimensional stability (Fig. 5). The predictions of pine wood models were over or under-estimated with no clear trend while predictions of the models for dimensional stability of eucalypt wood are under-estimated for the smaller values. These results were to be expected since dimensional stability measured as ASE depends not only on the treated wood sample but also on the untreated wood reference.

\subsection{Colour}

Table 4 gives some characteristics of the sample and of the best models to estimate surface colour given by lightness and chroma coordinates of the CIELAB method $\left(L^{*}, a^{*}\right.$ and $\left.b^{*}\right)$
Fig. 6 Experimental and predicted values for heat treated pine and eucalypt wood colour parameters $\left(L *, a^{*}\right.$ and $\left.b^{*}\right)$ Abb. 6 Experimentell bestimmte und berechnete Farbparameter $\left(L *, a^{*}\right.$ und $\left.b *\right)$ von wärmebehandeltem Kiefern- und Eukalyptusholz
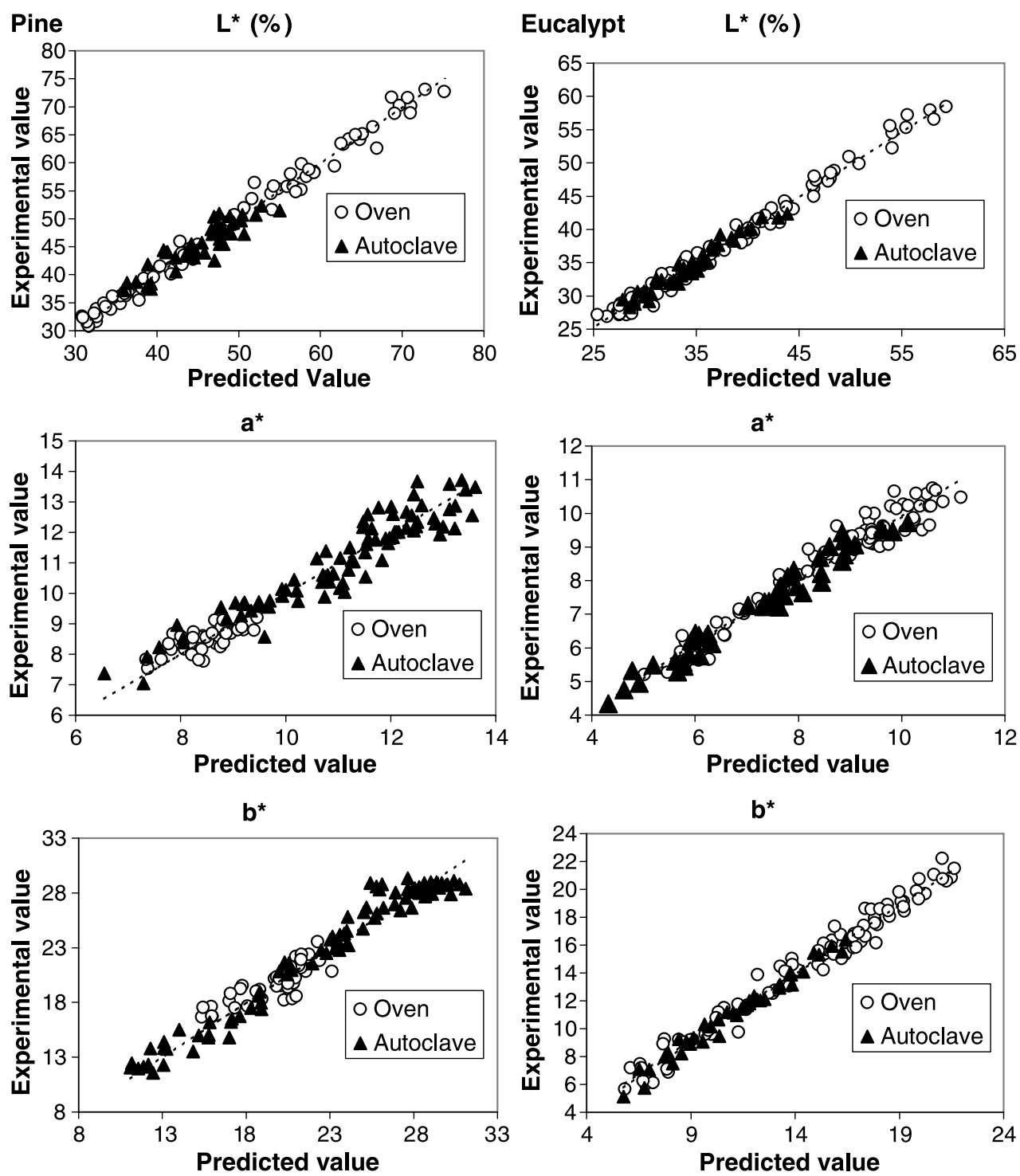
by NIR measurements for oven and autoclave heat treated pine and eucalypt wood. Although colour is even easier to measure than NIR spectra, these have the advantage of predicting several properties with the same spectrum.

All the models for lightness $\left(L^{*}\right)$ were very good with coefficients of determination ranging from $83.4 \%$ (autoclave treatment, pine) to $98.7 \%$ (oven treatment, pine and eucalypt). The predictive capacity of the model for lightness $\left(L^{*}\right)$ of oven treated pine wood was better than the model for autoclave, although with a very high rank (10 for oven and 1 for autoclave). The predictive abilities of eucalypt $L^{*}$ were better than for pine wood with $R^{2}$ of $98.7 \%$ for the oven treatment and $94.8 \%$ for the autoclave treatment, respectively.

These results are in accordance with $\mathrm{Wu}$ et al. (2005) who used NIR spectroscopy to assess the colour change in Eucalyptus grandis wood subjected to heat and steaming treatments. Mitsui et al. (2001) referred that NIR could be suitable to monitor a new colouring method of wood. Besides the good predictive capacity of the models for $L^{*}$ the rank was low, only 1 and 2 for the treatment in oven and autoclave, respectively (Table 4).

The models for $a^{*}$ gave worse results but still with a $R^{2}$ ranging from $51.6 \%$ (autoclave treatment, pine) to $96.4 \%$ (autoclave treatment, eucalypt). The models for pine had poorer predictive capacities than for eucalypt wood and similar rank 3 and 5 (pine) and 2 and 6 (eucalypt) for autoclave and oven treatment, respectively.

The predictive capacities of the models for $b^{*}$ were better than for $a^{*}$ and with a $R^{2}$ higher than $96 \%$ with the exception of the model for autoclave heat treated pine. The higher values of the $R^{2}$ for the models of oven heat treated pine wood are mainly due to the higher amplitude of the sample variation. The models for the chroma coordinate $a^{*}$ for eucalypt wood were much better than for pine wood although the number of main components was generally higher, 2 and 6 for oven and autoclave heat treated wood, respectively.

In general all the models for eucalypt wood colour parameters $\left(L^{*}, a^{*}\right.$ and $\left.b^{*}\right)$ were very good explaining more than $95 \%$ of the variation. Predictions were either under or over-estimated with no clear trend except for the $b^{*}$ model for oven heat treated pine wood that despite the high $R^{2}$ does not behave well for values higher than 28 , with predicted values higher than the real values (Fig. 6).

In the case of colour and NIR spectroscopy, both measurements are made on the surface of the samples, thereby eliminating one potential source of prediction loss due to within sample differences between surface and interior. Correspondingly the NIR-based prediction models for wood colour of heat treated wood were very good.

\subsection{Extractives}

Despite the small amount of tested samples, results for the calibration curves of dichloromethane, ethanol, water and total extractives are presented in Table 5.

In relation to dichloromethane extractives the $R^{2}$ for crossed validation was $41.9 \%$ for pine and $82.2 \%$ for eucalypt with RMSECV of 0.176 and 0.445 , respectively. The number of main components was 1 and 3 for pine and eucalypt models. The $R^{2}$ for the models of the ethanol extractives was 64.3 and $81.2 \%$ with RMSECV of 0.357 and 1.250 for pine and eucalypt wood, respectively. The rank is high, 4 and 8 for pine and eucalypt wood models, respectively.

The $R^{2}$ for the models of the water extractives were 79.8 and $35.3 \%$ with RMSECV of 1.24 and 1.69 for pine and eucalypt wood, respectively. The $R^{2}$ for pine was much smaller than the one reported by Gierlinger et al. (2002) with powder larch ( $R^{2}=92 \%$ for cross validation) but similar to the one obtained with solid wood $\left(R^{2}=81 \%\right.$ for cross
Table 5 Sample characteristics and selected models for dichloromethane, ethanol, water and total extractives for heat treated pine and eucalypt wood Tabelle 5 Anzahl und Art der Proben und ausgewählte Modelle für dichlormethan-, ethanol- und wasserlösliche Extraktstoffe sowie der Gesamtextraktstoffe von wärmebehandeltem Kiefernund Eukalyptusholz

\begin{tabular}{|c|c|c|c|c|c|c|c|}
\hline & & $\begin{array}{c}\text { No of } \\
\text { samples }\end{array}$ & $\begin{array}{c}\text { Amplitude } \\
(\%)\end{array}$ & $R^{2}$ & RMSECV & $\begin{array}{c}\text { Pre- } \\
\text { processing }\end{array}$ & $\begin{array}{c}\text { Spectral region } \\
\left(\mathrm{cm}^{-1}\right)\end{array}$ \\
\hline \multirow[t]{4}{*}{$\begin{array}{l}\text { Pine } \\
\text { extractives }\end{array}$} & Dichloromethane & 24 & $0.2-1.2$ & 41.9 & 0.18 & $\begin{array}{l}\text { No pre- } \\
\text { processing }\end{array}$ & $10001.5-7498.3$ \\
\hline & Ethanol & 24 & $1.4-3.4$ & 64.3 & 0.36 & $\begin{array}{l}\text { No pre- } \\
\text { processing }\end{array}$ & $10001.5-6098.1$ \\
\hline & Water & 24 & $1.2-10.1$ & 79.8 & 1.24 & $\begin{array}{c}\text { Vectorial } \\
\text { normalization }\end{array}$ & $7502.1-5446.3$ \\
\hline & Total & 24 & $2.2-14$ & 83.8 & 5.48 & 1st Derivative & $10001.5-5446.3$ \\
\hline \multirow[t]{4}{*}{$\begin{array}{l}\text { Eucalypt } \\
\text { Extractives }\end{array}$} & Dichloromethane & 24 & $0.4-4.2$ & 82.2 & 0.45 & $\begin{array}{l}\text { 1st Derivative } \\
\text { and vectorial } \\
\text { normalization }\end{array}$ & $\begin{array}{r}10001.5-7498.3 \\
5450.1-5099.1\end{array}$ \\
\hline & Ethanol & 24 & $4.5-16.3$ & 81.2 & 1.25 & 1st Derivative & $10001.5-5099.1$ \\
\hline & Water & 24 & $1.7-8.8$ & 35.3 & 1.69 & $\begin{array}{l}\text { Derivative } \\
\text { and linear } \\
\text { subtraction }\end{array}$ & $7502.1-6800.1$ \\
\hline & Total & 24 & $9.1-26.2$ & 34.3 & 2.99 & $\begin{array}{l}\text { Multiplicative } \\
\text { scattering } \\
\text { correction }\end{array}$ & $10001.5-5099.1$ \\
\hline
\end{tabular}


validation). This is understandable since in addition to the lesser number of analysed samples and the more heterogeneous nature of heat treated material there is the differences due to annual rings, sample geometry and surface properties as reported by Gierlinger et al. (2002). The best calibrations for water extracts were reached in the spectral region from 6800 to $7502 \mathrm{~cm}^{-1}$ differently from those reported by Gierlinger et al. (2002) with larch of 6100 to $5400 \mathrm{~cm}^{-1}$.

In relation to the total extractives $R^{2}$ was $83.8 \%$ for pine and $34.3 \%$ for eucalypt wood with RMSECV of 5.48 and 2.99 , respectively. The model reported by Kelley et al. (2004b) for total extractives of untreated Pinus taeda wood $\left(R^{2}=86 \%\right.$ ) had higher prediction capacity but according to Poke and Raymond (2006) who used NIR for the estimation of extractives, lignin and cellulose content in solid wood, extractives and acid-insoluble lignin gave poor predictions although cellulose and total lignin showed moderate relationships. The $R^{2}$ for pine was similar to the one obtained by Gierlinger et al. (2002) with acetone extract from larch $\left(R^{2}=84 \%\right)$.

The pre-processing techniques that led to the best models were different for all of the extracts although the 1st derivative alone or combined with other techniques usually gave better results. The predictions were not influenced by the type of treatment since there were no significant spectral differences between wood treated in oven or autoclave. However the small number of samples tested calls for caution in generalising the results.

\section{Conclusion}

NIR spectroscopy showed a good potential to be used for the assessment of heat treated wood, namely in quality control in the heat treatment of pine and eucalypt wood. Nevertheless substantial work has still to be done in order to use NIR as a tool in quality control. Every wood species and property requires calibration sets and the generation of these could be very time-consuming due to the large number of samples required and the slowness of most conventional methods for the measurement of wood properties. The number of tested samples for mechanical properties was also low, and in order to obtain a real calibration curve a larger number of samples needs to be tested.

NIR models for mass loss presented very good prediction ability with high coefficients of determination for cross validation ranging from $96-98 \%$. The models for heat treated wood properties were in general good with coefficients of determination ranging from 78 to $95 \%$ for equilibrium moisture content, $53-78 \%$ for dimensional stability, $47-89 \%$ for MOE, $75-77 \%$ for bending strength and 84-99\%, 52-96\% and $66-98 \%$ for the colour parameters $L, a^{*}$ and $b^{*}$, respectively. There were no significant spectral differences between wood treated in oven or autoclave. Therefore, NIR spectroscopy of the wood solid surface can be applied to estimate several properties that can be related to the intensity of treatment or to the properties targeted for improvement, e.g. equilibrium moisture and dimensional stability.

Overall one NIR spectrum of the solid surface of a heat treated wood sample gave information on the process extent (by estimating mass loss) and on the properties that are relevant for this wood modification and for the uses of heat treated wood, i.e. equilibrium moisture content, dimensional stability and extractives. Therefore and given that the acquisition of NIR spectra can be done quickly and easily on the solid surface of the samples using a fibre probe, and that spectral data processing can be done immediately afterwards, this is a methodology with an interesting potential for process and product quality control, once calibration and validation of the models have been made for the processed wood species.

Acknowledgement The authors would like to thank Dr. José Carlos Rodrigues for his help on spectral data handling and interpretation of NIR models and the Forests and Forest Products Centre of the Tropical Research Institute (IICT) for making available the NIR spectrometer.

\section{References}

Alves A, Schwanninger M, Pereira H, Rodrigues J (2006) Calibration of NIR to assess lignin composition (H/G ratio) in maritime pine wood using analytical pyrolysis as the reference method. Holzforschung 60:29-31

Baillères H, Davrieus F, Pichavant FH (2002) Near infrared analysis as a tool for rapid screening of some major wood characteristics in a eucalyptus breeding program. Ann For Sci 59:479-490

Brischke C, Welzbacher C, Brandt K, Rapp A (2007) Quality control of thermally modified timber: Interrelationship between heat treatment intensities and CIE $L^{*} a^{*} b *$ color data on homogenized wood samples. Holzforschung 61:19-22

Dirol D, Guyonnet R (1993) Durability by rectification process. Int Res Group Wood Pre Section 4-Processes No IRG/WP 93-40015

Esteves B, Domingos I, Pereira H (2007a) Improvement of technological quality of eucalypt wood by heat treatment in air at 170-200 ${ }^{\circ}$ C. For Prod J 57(1/2):47-52

Esteves B, Velez Marques A, Domingos I, Pereira H (2007b) Influence of steam heating on the properties of pine (Pinus pinaster) and eucalypt (Eucalyptus globulus) wood. Wood Sci Technol 41:193-207

Esteves B, Velez Marques A, Domingos I, Pereira H (2007c) Heat induced colour changes of pine (Pinus pinaster) and eucalypt (Eucalyptus globulus) wood. Wood Sci Technol 42:369-384

Gierlinger N, Schwanninger M, Hinterstoisser B, Wimmer R (2002) Rapid determination of heartwood extractives in Larix sp by means of Fourier transform near infrared spectroscopy. J Near Infrared Spec 10:203-214

Gindl W, Teischinger A, Schwanninger M, Hinterstoisser B (2001) The relationship between near infrared spectra of radial wood surfaces and wood mechanical properties. J Near Infrared Spectroscopy 9:255-261 
Hakkou M, Pétrissans M, Gérardin P, Zoulalian A (2006) Investigation of the reasons for fungal durability of heat-treated beech wood. Polym Degrad Stab 91:393-397

Hinterstoisser B, Schwanninger M, Stefke B, Stingl R, Patzelt M (2003) Surface Analyses of Chemically and Thermally Modified Wood by FT-NIR. Proceedings of the First European Conference on Wood Modification, 3-4 April 2003, Ghent, Belgium

Hoffmeyer P, Pedersen JG (1995) Evaluation of density and strength of Norway spruce wood by near-infrared reflectance spectroscopy. Holz Roh- Werkst 53:165-170

Holmgren A, Bertgstrom B, Gref R, Ericsson A (1999) Detection of pinosylvins in solid wood of Scots pine using Fourier transform Raman and infrared spectroscopy. J Wood Chem Technol 19:139-150

Jämsä S, Viitaniemi P (2001) Heat treatment of wood - Better durability without chemicals. Proceedings of the special seminar of COST Action E22, 9 February 2001, Antibes, France

Jämsa S, Ahola P, Viitaniemi P (2000) Long-term natural weathering of coated ThermoWood. Pigm Resin Technol 29(2):68-74

Jones P, Schimleck L, Peter G, Daniels R, Clark A (2005) Nondestructive estimation of Pinus taeda $\mathrm{L}$ wood properties for samples from a wide range of sites in Georgia. Can J Forest Res 35:85-92

Kamdem D, Pizzi A, Jermannaud A (2002) Durability of heat treated wood. Holz Roh- Werkst 60:1-6

Kelley S, Rials T, Snell R, Groom L, Chi-Leung S (2004a) Use of near infrared spectroscopy to predict the mechanical properties of six softwoods. Holzforschung 58:252-260

Kelley S, Rials T, Snell R, Groom L, Sluiter A (2004b) Use of near infrared spectroscopy to measure the chemical and mechanical properties of solid wood. Wood Sci Technol 38:257276

Mitsui K, Takada H, Sugiyama M, Hasegawa R (2001) Changes in the properties of light-irradiated wood with heat treatment: Part 1 Effect of treatment conditions on the change in color. Holzforschung 55:601-605

Osborne BG, Fearn T, Hindle PH (1993) Practical NIR Spectroscopy with Applications in Food and Beverage Analysis. Longman Scientific-Technical, Harlow, Essex

Poke FS, Raymond CA (2006) Predicting extractives lignin and cellulose contents using near infrared spectroscopy on solid wood in Eucalyptus globulus. J Wood Chem Technol 26:187-199

Poke FS, Wright JK, Raymond CA (2004) Predicting extractives and lignin contents in Eucalyptus globulus using near infrared reflectance analysis. J Wood Chem Technol 24:55-67

Rapp A, Brischke C, Welzbacher C (2006) Interrelationship between the severity of heat treatments and sieve fractions after impact ball milling: a mechanical test for quality control of thermally modified wood. Holzforschung 60:64-70
Rodrigues J, Alves A, Pereira H, Perez D, Chantre G, Schwanninger M (2006) NIR PLSR results obtained by calibration with noisy low-precision reference values: Are the results acceptable? Holzforschung 60(4):402-408

Schimleck LR, Evans R (2003) Estimation of air-dry density of increment cores by near infrared spectroscopy. Appita J 56:312317

Schimleck LR, Evans R, Ilic J (2001) Estimation of Eucalyptus delegatensis wood properties by near infrared spectroscopy. Can J Forest Res 31:1671-1675

Schimleck LR, Wright PJ, Michell AJ, Wallis AFA (1997) Near infrared spectra and chemical compositions of $E$ globulus and $E$ nitens plantation woods. Appita J 50:40-46

Schimleck LR, Jones PD, Clark A, Daniels RF, Peter GF (2005) Near infrared spectroscopy for the nondestructive estimation of clear wood properties of Pinus taeda $\mathrm{L}$ from the southern United States. For Prod J 55:21-28

Schultz T, Burns D (1990) Rapid secondary analysis of lignocellulose: comparison of near infrared (NIR) and Fourier transform infrared (FTIR). Tappi J 5:209-212

Schwanninger M, Hinterstoisser B, Gierlinger N, Wimmer R, Hanger J (2004) Application of Fourier Transform Near Infrared Spectroscopy (FT-NIR) to thermally modified wood. Holz RohWerkst 62(6):483-485

Thumm A, Meder R (2001) Stiffness prediction of radiata pine clear wood test pieces using near infrared spectroscopy. J Near Infrared Spec 9:117-122

Thygesen LG, Lundqvist SO (2000a) NIR measurement of moisture content in wood under unstable temperature conditions Part 1 Thermal effects in near infrared spectra of wood. J Near Infrared Spec 8:183-189

Thygesen LG, Lundqvist SO (2000b) NIR measurement of moisture content in wood under unstable temperature conditions Part 2 Handling temperature fluctuations. J Near Infrared Spec 8:191199

Tsuchikawa S, Torii M, Tsutsumi S (1996) Application of near infrared spectrophotometry to wood 4 Calibration equations for moisture content. Mokuzai Gakkaishi 42:743-754

Viitaniemi P, Jämsä S, Viitanen H (1997) Method for improving biodegradation resistance and dimensional stability of cellulosic products. United States Patent No 5678324 US005678324

Wang J, Cooper P (2005) Effect of oil type temperature and time on moisture properties of hot oil-treated wood. Holz Roh- Werkst 63:417-422

Wu Y, Tsuchikawa S, Hayashi K (2005) Application of near infrared spectroscopy to assessments of colour change in plantation-grown Eucalyptus grandis wood subjected to heat and steaming treatments. J Near Infrared Spec 13(6): 371-376 